\title{
Efek Pemberian Eugenol Isolat Bunga Cengkeh (Syzygium aromaticum) terhadap Histologi Pankreas Tikus Diabetes
}

\section{(Eugenol Effect of Clove Flower (Syzygium aromaticum) Isolate on Histology Pancreas of Diabetic Rat)}

\author{
SINTAWAHYU UTAMI, I MADE SUDARMA*, CANDRA DWIPAYANA HAMDIN \\ Fakultas Kedokteran, Fakultas MIPA Universitas Mataram jalan Majapahit \\ Kota Mataram, 83115, Indonesia \\ *Penulis korespondensi, Hp : 085339370602 \\ e-mail: sud_arma@yahoo.com
}

\section{Diterima 23 Januari 2019, Disetujui 12 September 2019}

\begin{abstract}
Abstrak: Diabetes melitus merupakan penyakit yang prevalensinya tinggi di Indonesia, dari tahun ketahun prevalensinya terus meningkat. Sehingga sebagian peneliti mulai melakukan eksplorasi bahan alam dalam pencegahan maupun penanganan diabetes melitus. Bunga Cengkeh (Syzygium aromaticum) mengandung senyawa eugenol yang secara ilmiah dapat menurunkan kadar gula darah. Penelitian ini bertujuan untuk mengetahui efek pemberian eugenol isolat bunga cengkeh terhadap histologi pankreas tikus diabetes. Bunga cengkeh diektraksi menggunakan metode maserasi menggunakan pelarut n-heksan, kemudian eugenol disolasi menggunakan metode asam-basa kemudian diuji dengan KLT. Pengaruh pemberian eugenol dilihat dengan menginduksi aloksan dengan dosis $125 \mathrm{mg} / \mathrm{kgBB}$ secara intraperitoneal kemudian emulsi eugenol dosis $10 \mathrm{mg} / \mathrm{KgBB}$ dibandingkan dengan glibenklamid 1,35 $\mathrm{mg} / \mathrm{KgBB}$ secara oral selama 14 hari kemudian dilakukan histologi pankreas. Pengamatan hasil histologi pankreas dilakukan dengan membuat preparat pankreas menggunakan pengecatan Hematoxilin Eosin (HE). Hasil penelitian menunjukan tikus yang diinduksi aloksan mengalami kerusakan sel pankreas. Namun, setelah diberikan perlakukan glibenklamid dan senyawa eugenol mampu memperbaiki sel pankreas yang mengalami kerusakan akibat pemberian aloksan
\end{abstract}

Kata kunci: Cengkeh, eugenol, antidiabetes, histolog pankreas.

\begin{abstract}
Diabetes mellitus is disease with a high prevalence rate and continuously increase in Indonesia. So some researchers began to glance at natural rescource for prevention and treatment of diabetes mellitus. Clove Flower (Syzygium aromaticum) contains eugenol that can chemically lower blood sugar levels. The aimed of this research is to know the effect of eugenol on pancreas histology of diabetic rats. Clove flowers was extracted used maseration method use n-hexan and eugenol was isolated tested with TLC. Alloxan-induced rats were dosed $125 \mathrm{mg} / \mathrm{kg} \mathrm{BW}$ IP and then the eugenol was administered in dosage $10 \mathrm{mg} / \mathrm{kg} \mathrm{BW}$ compared with glibenclamid $1,35 \mathrm{mg} / \mathrm{Kg} \mathrm{BW}$ orally for 14 days. Observation of pancreatic histology results were made pancreatic preparations using Hematoxilin Eosin (HE) staining. The results showed that alloxan-induced rats had pancreatic cell damage. How ever, after being treated with Glibenclamide and Eugenol showed the improvement of damage organs. Giving the eugenol at a dose of $15 \mathrm{mg} / \mathrm{kg}$ BW showed the most significant improvement.
\end{abstract}

Keywords: Clove flower, eugenol, antidiabetic, pancreatic histology. 


\section{PENDAHULUAN}

POLA hidup yang tidak sehat menyebabkan terjadinya peningkatan resiko penyakit metabolik, salah satunya yaitu diabetes melitus ${ }^{(1)}$. Diabetes melitus merupakan penyakit yang disebabkan karena adanya kelainan metabolisme glukosa. Gangguan metabolisme glukosa secara kontinyu menyebabkan sistem biologis berupaya untuk memperbaiki ketidakseimbangan metabolisme tersebut sehingga akan terjadi kerusakan pada sistem endokrin ${ }^{(2,3)}$

Prevalensi diabetes melitus semakin meningkat hal ini dibuktikan Pada tahun 2015 di Indonesia jumlah penderita diabetes sebesar 10,3 juta dan diperkirakan pada tahun 2045 akan meningkat sebesar 16,7 juta $^{(4)}$. Saat ini sebagian besar peneliti mulai tertarik untuk melakukan eksplorasi bahan alam dengan ketersediaan melimpah serta memiliki kandungan bioaktif. Sehingga dapat dimanfaatkan dalam pencegahan maupun pengobatan diabetes dengan efek samping minimal ${ }^{(3)}$.

Salah satu tanaman yang jumlahnya melimpah di Indonesia adalah cengkeh (Syzygium aromaticum). Bunga cengkeh banyak mengandung senyawa kimia seperti eugenol dan kariofilen dan telah diuji efek farmakologi eugenol sebagai hepatoprotektor ${ }^{(5)}$. Senyawa ini juga digunakan sebagai antifungal karena memiliki selektivitas yang tinggi dalam menghambat pertumbuhan C. albicans, C. krusei dan C. glabrata $^{(6)}$. Pada dosis $80 \mathrm{mg} / \mathrm{KgBB}$ senyawa eugenol memiliki efek hipoglikemik dengan menghambat enzim $\alpha$-amylase dan mampu meregenenerasi sel $\beta$ pankreas ${ }^{(7)}$. Berdasarkan penelitian yang telah dilakukan maka peneliti ingin mengetahui efek pemberian eugenol isolat bunga Cengkeh (Syzygium aromaticum) pada dosis $10 \mathrm{mg} / \mathrm{KgBB}$, terhadap histologi pankreas tikus diabetes.

\section{BAHAN DAN METODE}

BAHAN. Bahan yang digunakan dalam penelitian ini adalah albumin mayer's, aquadest, alkohol bertingkat, bunga cengkeh(Syzigium aromaticum), dikhlorometana (DCM), eugenol standar, formalin $10 \%$, HCL pekat, hewan uji tikus jantan galur wistar, kertas label, kertas saring biasa, kertas saring whatman, kloroform, $\mathrm{Na}_{2} \mathrm{SO}_{4}$ anhidrat, n-heksan, pakan standar, paraffin, pewarna eosin, pewarna hematoksilin, plat klt, tissue, xilol

ALAT. Alat-alat yang digunakan dalam penelitian ini adalah alat tulis, batang pengaduk, beaker glass, botol vial, blok kayu, chamber, corong biasa, corong pisah, dissecting set, entellan, gelas kimia, gelas ukur erlenmeyer, jarum, lampu uv 245 $\mathrm{nm}$, magnet stirrer, mikrotom, mortar, neraca analitik, papan operasi, pipet volume, pipet tetes, pipa kapiler, pinset, rotary evaporator, rubber bulb,spuit $5 \mathrm{cc}$, stamper, timbangan, pot sampel, water bath.

METODE. Ekstraksi bunga cengkeh. Bunga cengkeh kering yang sudah diblender $(500 \mathrm{~g})$ dimaserasi dengan n-heksan (3,5 L) selama 24 jam. Kemudian disaring dan filtrat ditampung dalam erlenmeyer sedangkan residunya diektraksi kembali dengan n-heksan selama 24 jam. Filtrat yang dihasilkan digabungkan dengan filtrat sebelumnya kemudian dievaporasi. Ekstrak kental kemudian ditimbang dan diuji menggunakan KLT yang dibandingkan dengan standar. Fase diam yang digunakan silika gel dan fase geraknya menggunakan DCM : n-heksan (3:1).

Isolasi Eugenol. Ekstrak kental dilarutkan dengan DCM. Campuran ekstrak- DCM ditambahkan dengan $\mathrm{NaOH}$ yang telah dilarutkan dengan aquadest. Campuran tersebut kemudian distirrer suhu kamar. Lapisan yang berada dibawah dan berwarna coklat dipisahkan dari fase air yang berupa garam eugenolat. Kemudian diasamkan dengan menambahkan $\mathrm{HCl}$ pekat dengan $\mathrm{pH}=3$. Lapisan bawah (A) dikeluarkan dari corong pisah dan ditampung dalam gelas kimia. Lapisan atas diekstrak dengan DCM, kemudian diambil lapisan bawahnya (B) disatukan dengan lapisan bawah (A). Campuran kemudian dicuci dengan air sampai $\mathrm{pH}$ air netral. Setelah campuran netral, maka lapisan bagian bawah (eugenol kotor) dan kemudian disaring dengan pelarut DCM: n-heksan (1:1) dan pelarut yang tersisa diuapkan. Kemudian dilakukan pengujian dengan KLT dan penentuan kadar menggunakan GC-MS ${ }^{(8,9)}$.

Pengujian secara in vivo. 36 ekor tikus wistar yang digunakan sebagai hewan uji yang telah melewati telaah etik dengan No: 87/UN18.8/ETIK/2018. Kemudian dibagi menjadi kelompok kontrol $(+)$, kontrol (-) dan kontrol normal, dan tiga kelompok perlakuan dimana masing-masing kelompok terdiri dari 6 ekor tikus. Selanjutnya dilakukan induksi aloksan secara intraperitoneal dengan dosis 125 $\mathrm{mg} / \mathrm{kgBB}$ kepada masing-masing hewan uji kecuali kelompok kontrol normal. Kelompok kontrol positif diberikan glibenklamid secara oral dengan dosis $1,35 \mathrm{mg} / \mathrm{kgBB}$, kelompok kontrol negatif diberikan CMC-Na, sedangkan kelompok perlakukan diberikan eugenol dosis $10 \mathrm{mg} / \mathrm{Kg}$ BB selama 14 hari. Setelah perlakukan selama 14 hari, semua hewan uji di otopsi dan dilakukan pengamatan terhadap sel.

Histologi pankreas. Hewan uji dibius menggunakan kloroform kemudian organ pankreas diisolasi dan dilakukan penimbangan organ. Organ yang sudah diisolasi kemudian difiksasi menggunakan 
formalin dan dilakukan rehidrasi menggunakan alkohol bertingkat dengan konsentrasi 30\%, 50\%, $60 \%, 70 \%, 80 \%$, dan $96 \%$. Selanjutnya dilakukan pembenaman paraffin dan dilakukan pemotongan organ dengan mikrotom dengan ukuran 3-4 mikron. Pewarnaan dilakukan dengan hematoxilin dan eosin. Hasil histologi diamati menggunakan mikroskop cahaya dengan perbesaran 40x.

\section{HASIL DAN PEMBAHASAN}

Ekstraksi sampel. Hasil pengujian kromatograpi lapis tipis menunjukan bahwa nilai $\mathrm{Rf}$ antara ekstrak bunga cengkeh dengan $\mathrm{Rf}$ standar eugenol adalah sama yaitu 0,75 . Hal tersebut menunjukan bahwa dalam ekstrak bunga cengkeh terdapat kandungan senyawa eugenol.

Histologi pankreas. Pada tabel 1 menunjukan bahwa index organ pada masing-masing kelompok menunjukan tidak terjadi perbedaan yang signifikan $(\mathrm{P}>0,05)$. Walaupun demikian data index organ tidak dapat digunakan sebagai patokan adanya kerusakan atau perbaikan pada $\operatorname{sel}^{(10)}$.

Tabel 1. Index organ pankreas

\begin{tabular}{cc}
\hline Kelompok & $\begin{array}{c}\text { Index organ(\%) } \\
\text { Mean } \pm \mathrm{SD}\end{array}$ \\
\hline Eugenol dosis $10 \mathrm{mg} / \mathrm{kg}$ & $0,165 \pm 0,037$ \\
BB & $0,194 \pm 0,044$ \\
Kontrol normal & $0,201 \pm 0,055$ \\
Kontrol negatif & $0,047 \pm 0,243$ \\
\hline
\end{tabular}

Hasil pengamatan pada masing-masing kelompok berdasarkan gambar 1 menunjukan bahwa tikus yang diberikan aloksan mengalami kerusakan pada sel pankreas meskipun terdapat variasi pada masing-masing individu tikus. Kerusakan sel pankreas ditandai dengan adanya nekrosis, kongesti, udema, vakuolisasi, dan dilatasi sel langerhan. Nekrosis merupakan kematian sel sebagai akibat dari kerusakan sel akut yang tidak terkontrol. Nekrosis dapat meyebabkan lisis pada sel yang dicirikan dengan adanya vakuola ${ }^{(10)}$. Sedangkan edema yaitu penambahan volume cairan yang ditandai dengan terbentuknya rongga kosong pada islet langerhan ${ }^{(11)}$.

Aloksan bekerja dengan menghasilkan spesies oksigen reaktif yaitu hydrogen peroksida $\left(\mathrm{H}_{2} \mathrm{O}_{2}\right)$ dan radikal bebas hidroksi $(\mathrm{OH})$ yang sangat reaktif dalam menyerang molekul biologis sehingga berdampak pada kerusakan sel pankreas ${ }^{(12)}$. Pemberian emulsi eugenol memperlihatkan kondisi sel pankreas yang mulai membaik. Namun, pada masing-masing kelompok menunjukan perbaikan yang bervariasi. Pada pemberian dosis $10 \mathrm{mg} / \mathrm{kg}$ BB menunjukan adanya vakuola lemak(VL) namun tidak terjadi kerusakan sel. Hasil hitologi pada kontrol positif yang diberikan perlakukan suspensi glibenklamid menunjukan adanya perbaikan, hal ini sesuai dengan teori bahwa meknaisme kerja glibenklamid adalah dengan membangtu regenerasi sel $\beta$ dan membantu meningkatkan pengeluaran insulin sehingga kadar gula darah dapat terkontrol ${ }^{(13)}$. Pada penelitian sebelumnya yang mengkaji efek senyawa eugenol memberikan
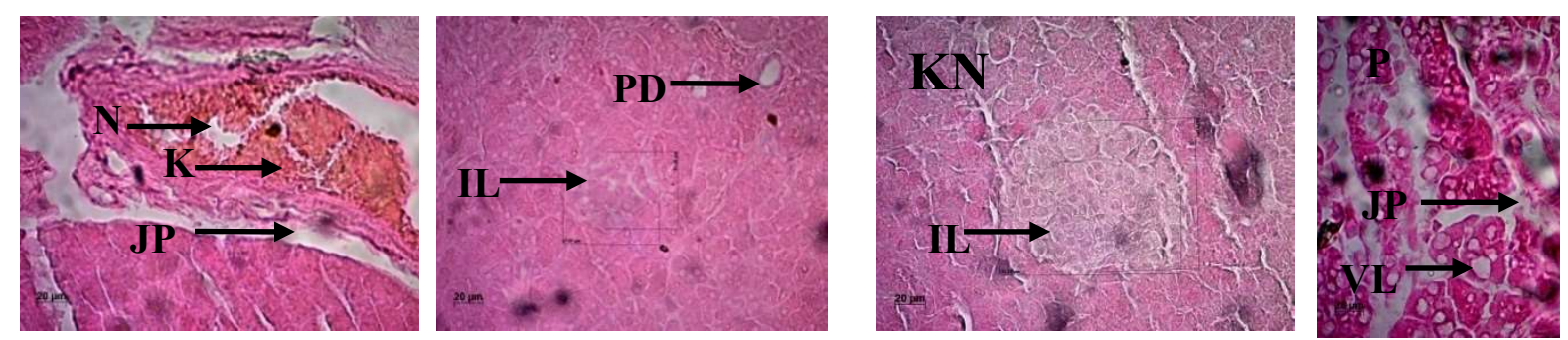

Gambar 1 Histologi masing-masing kelompok. (K+) kontrol positif 40x; (K-) kontrol negatif; (KN) kontrol normal 40x; (P1) Perlakuan dosis $10 \mathrm{mg} / \mathrm{kg} \mathrm{BB}$.

hipotesis bahwa senyawa eugenol bertindak sebagai penghambat enzim $\alpha$ amylase dan $\alpha$ glukosidase yang dapat menghambat penyerapan karbohidrat sehingga dapat dirubah menjadi glukosa ${ }^{(7)}$. Hasil histologi pankreas pada penelitian ini menunjukan bahwa senyawa eugenol mampu memperbaiki kerusakan sel pankreas, sehingga mampu membantu dalam mensekresikan insulin. Oleh karena itu, kadar gula darah puasa dan $\mathrm{HbA} 1 \mathrm{c}$ dapat menurun dengan pemberian emulsi eugenol ${ }^{(3)}$.

\section{SIMPULAN}

Pemberian senyawa eugenol mampu memperbaiki kerusakan sel pankreas pada tikus diabetes yang diinduksi aloksan. Pemberian senyawa eugenol pada dosis $10 \mathrm{mg} / \mathrm{kg}$ BB tikus menunjukan adanya perbaikan sel pankreas. 


\section{UCAPAN TERIMA KASIH}

Ucapan terima kasih penulis sampaikan kepada Prof. Ir. I Made Sudarma, M.Sc., Ph. D membiayai penelitian ini melalui skill penelitian berbasis kompetensi Ristek Dikti Th. 2018 dan kepada Candra Dwipayana Hamdin, S. Farm., M.Sc., Apt selaku dosen pembimbing II yang telah meluangkan waktu untuk membimbing serta mengarahkan sehingga penelitian ini dapat terselesaikan.

\section{DAFTAR PUSTAKA}

1. Wahyuni, R., Arsunan, A.A.,Zulkifli Abdullah A. 2013. Factor Releted to Anciety Levels In Patients With Diabete Mellitus Type 2 Bhayangkara Andi Mappang Audang Hospital. Makassar : Universitas Hasanuddin.

2. Dipiro, J. T., Talbert, R. L., Yee, G. C., Matzke, G. R., Wells, B. G., and Posey, L. M., 2015. Pharmacotherapy : Patophysiologic Approach. 9th Edition, New York: MC Graw Hill, hal. 212-210.

3. Srinivasan, S., Sathis, G., Jayanthi, M., Muthukumaran, J., Muruganthan, U., Ramachandran, V., 2013. Ameliorating effect of eugenol on hyperglycemia by attenuating the key enzymes of glucose metabolism in streptozotocin-induced diabetic rats. Mol Cell Biochem., Vol. 385 No. 2, pp. 159-168. Diakses dari https://www.ncbi.nlm.nih.gov/pubmed/24078031, pada tanggal 21 Januari 2019.

4. Cho, N. Han., Whiting, D., Forouhi, N., Guariguata, L., Hambleton, I., Li, R., Majeed, A., Mbanya, J. C., Montoya, P. A., Motala, A., Narayan, K. M. V., , Ramachandran, A., Rathmann, W., Roglic. G., Shaw, J., Silink, M., and Zhang, P. Internasional Diabetes Federation Diabetes Atlas. 7Th Edition. Diakses dari www.idf.org/e-library/epidemiology-research/ diabetes-atlas/134-idf-diabetes-atlas-8th-edition.html, pada tanggal 27 Desember 2017.

5. Sidabutar, D. M., Kairupan, C. F., dan Meilany, D., 2016. Pengaruh pemberian ekstrak daun cengkeh (Syzygium aromaticum) terhadap gambaran histopatologik hati tikus wistar yang diberikan parasetamol dosis toksik. Jurnal e-Biomedik (eBm)., Vol. 4 No. 1, pp. 1-4. Diakses dari https://ejournal. unsrat.ac.id/index.php/ebiomedik/article/view/12224, 21 Januari 2019.

6. Abrao, P.H.O., Pizi, R.B., Souza, T.B.d., Silva, N.C., and Fregnan, A.M. Synthesis And Biological Evaluation Of New Eugenol Mannich Bases As Promising Antifungal Agent. Diakses dari http: Onlinelibrary.wiley.com//10.111/cbdd.12345/full, Pada tanggal 16 Januari 2018.

7. Mnafgui, K., Kaanich, F., Derbali, A., Hamden, K., Derbali, F., Slama, S., Allouche, N., and Elfeki, A., 2013. Inhibition of key enzymes related to diabetes and hypertension by Eugenol Invitro and in Alloxaninduced diabetic rats. Arch Physiol Biochem., Vol. 119
No. 5, pp. 1-9 Diakses dari https://www.tandfonline. com/doi/abs/10.3109/13813455.2013.822521, pada tanggal 22 Desember 2018.

8. Sudarma, M., Ulfa, M., Sarkono, 2009. Sintesis 4-Allil-2-metoksi-6-aminofenol dari Senyawa Bahan Alam Eugenol. Indo. J. Chem., Vol. 9 No. 1, pp. 8488. Diakses dari https://journal.ugm.ac.id/ijc/article/ viewFile/21566/14271, pada tanggal 21 Januari 2019.

9. Risayanti, Made Dwi, 2017, Penambahan Basa Organik ( Heksamina) dan Basa Anorganik (Natrium Bikarbonat) Pada Reaksi Sulfonasi Eugenol Hasil Isolasi Minyak Cengkeh, Skripsi, Mataram : Universitas Mataram.

10. Azhari, B., Luliana, sri., Robiyanto, 2017. Uji Aktivitas Antihiperkolesterolemia Ekstrak AirBuah Belimbing Wuluh (Averrhoa bilimbi Linn.) Pada Permodelan Tikus Jantan Galur Wistar Hiperkolesterolemia. Traditional Medicine Journal. Vol. 4, No 1, pp : 57-62, Diakses dari pada tanggal 20 Januari 2019.

11. Akrom, Harjani, P.D., dan Armansyah. Efek Hipoglikemik Ekstrak Etanol Umbi Ketela Rambat (Ipomoea Batatas P) (Eeukr) Pada Mencit Swiss Yang Diinduksi Aloksan. Pharmaciana, Vol.4, No.1, p : 65-76. Diakses dari http://eprints.uad.ac.id/8612/, pada Departemen kesehatan Republik Indonesia. 2008. Keputusan Menteri Kesehatan Repubik Indonesia Nomor 261/MENKES/SK/IV/2009 tentang Farmakope Herbal Indonesia Edisi Pertama. Jakarta : Departemen Kesehatan Repubik Indonesia.

12. Muliasari, H., Hamdin, C.D., Ihsan, M., 2017. Histologi Pankreas Tikus Diabetes Setelah Pemberian Suspensi Biji Buah Makasar (Brucea Javanica (L.) Merr). BioWallacea Jurnal Ilmiah Ilmu Biologi., Vol.3 No. 2, pp 88-93. Diakses dari http://eprints.unram. ac.id/10077/, pada tanggal 22 Desember 2018.

13. Lanzen, S., 2008. The Mechanism of alloxan and Streptozotocin Induced Diabetes. Diabetologia, Vol. 52. No. 2, pp. 226-216.

14. Krentz, A.J., and Bailey, C. J., 2005. Oral Antidiabetic Agents Current Role in Type 2 Diabetes Mellitus. UK : Aston University, Hal. 398-390. 